\title{
Formation and Evolution of Al-Ti Oxide Inclusions during Secondary Steel Refining
}

\author{
Marie-Aline VAN ENDE, ${ }^{1)}$ Muxing GUO, ${ }^{1)}$ Rob DEKKERS, ${ }^{1)}$ Marc BURTY, ${ }^{2)}$ Joris VAN DYCK, ${ }^{1)}$ \\ Peter Tom JONES, ${ }^{1)}$ Bart BLANPAIN ${ }^{1)}$ and Patrick WOLLANTS ${ }^{11}$
}

1) Department of Metallurgy and Materials Engineering, Katholieke Universiteit Leuven, Kasteelpark Arenberg 44 box 2450 , BE-3001 Heverlee, Belgium. E-mail: MarieAline.VanEnde@mtm.kuleuven.be

2) ArcelorMittal Burns Harbor, 250 W.

U.S. Highway 12, Burns Harbor, IN 46304-9745, USA.

(Received on January 14, 2009; accepted on March 31, 2009)

\begin{abstract}
The process of $\mathrm{Al}$ deoxidation and $\mathrm{Ti}$ alloying during $\mathrm{RH}$ degassing treatment was studied under an $\mathrm{Ar}$ atmosphere at secondary steelmaking temperature $\left(1600-1650^{\circ} \mathrm{C}\right)$ in an induction furnace equipped with an oxygen probe and a steel sampler. The formation of inclusions during partial Al deoxidation and Ti addition, and the reduction of Ti-Al-O inclusions by second Al addition are discussed using thermodynamic calculations. Specific attention is given to inclusion size and the compositional relation between the inclusions and the steel. The combination of experimental and calculated results shows that, in order to prevent Ti oxidation in liquid steel, it is essential to control [Al] in liquid steel to a level of approximately 200 ppm prior to Ti addition to achieve around 500 ppm [Ti] with minimal Ti loss during the alloying process.
\end{abstract}

KEY WORDS: IF steel; Al-Ti deoxidation; Ti alloying; Al-Ti-O inclusions; Fe-Al-Ti-O equilibrium diagram.

\section{Introduction}

Ti stabilized IF (interstitial free) steel is commonly produced by the combination of primary (BOF) and secondary steelmaking (RH degassing treatment), during which $\mathrm{Ti}$ is added as an alloying element. Since Ti is substantially more expensive than $\mathrm{Al}$, it is added after $\mathrm{Al}$ deoxidation in order to minimize losses through reaction with oxygen. However, if thermodynamic and kinetic conditions allow, Ti will react with oxygen in the molten steel and/or with $\mathrm{Al}_{2} \mathrm{O}_{3}$ during the Ti alloying process. These reactions lead to the formation of Ti containing inclusions, which influence Ti yield during alloying and also steel cleanliness. The formation of non-metallic inclusions such as $\mathrm{Al}_{2} \mathrm{O}_{3}, \mathrm{TiO}_{x}$, and $\mathrm{Al}-\mathrm{Ti}-\mathrm{O}$ oxides might cause both nozzle clogging during continuous casting and loss of final product quality. ${ }^{1)}$ From the viewpoint of "oxide metallurgy", Ti containing complex oxides can be utilized as nuclei for $\mathrm{MnS}$ precipitation, ${ }^{2)}$ which can serve again as nucleation site for acicular ferrite after welding or heat treatment, hence improving steel toughness and strength. ${ }^{3,4)}$ It is, therefore, of great concern to study the combined oxidation of [Al] and [Ti] in order to try to understand the formation mechanisms of $\mathrm{Ti}$ containing oxides. The symbol [ ] refers to concentration in liquid steel.

Several authors ${ }^{5-8)}$ have investigated $\mathrm{Al} / \mathrm{Ti}$ and $\mathrm{Ti} / \mathrm{Al}$ deoxidation using sampling techniques. Kunisada et al. ${ }^{5,6)}$ reported that in the case of $\mathrm{Ti} / \mathrm{Al}$ deoxidation, the oxygen content in the liquid steel is lower than in the case of single Ti deoxidation but higher than in case of single Al deoxidation. Hence, there is no advantage of $\mathrm{Ti} / \mathrm{Al}$ deoxidation for reducing the oxygen content compared with single $\mathrm{Al}$ deox- idation. They observed that angular $\mathrm{Al}_{2} \mathrm{O}_{3}$ inclusions that had been formed during $\mathrm{Al}$ deoxidation, changed after $\mathrm{Ti}$ addition to spherical inclusions containing a small amount of $\mathrm{Ti}$, while, in the case of $\mathrm{Ti} / \mathrm{Al}$ deoxidation, $\mathrm{TiO}_{x}$ resulting from $\mathrm{Ti}$ deoxidation was reduced by the second $\mathrm{Al}$ addition. Ruby-Meyer et al. ${ }^{7}$ performed inclusion analyses in Tideoxidized steel and multiphase equilibrium calculations based on the IRSID slag model (code CEQCSI). They observed that $\mathrm{Al}_{2} \mathrm{O}_{3}$ inclusions were formed at high [Al] content, whereas inclusions containing both $\mathrm{Ti}$ oxides and $\mathrm{Al}_{2} \mathrm{O}_{3}$ were formed at low $\mathrm{Al}$ contents. There was a good correlation between the analyzed oxide composition and that predicted by the calculated $\mathrm{Fe}-\mathrm{Al}-\mathrm{Ti}-\mathrm{O}$ inclusion diagram. More recently, Matsuura et al. ${ }^{8)}$ investigated the inclusion evolution at $1600^{\circ} \mathrm{C}$ during $\mathrm{Al}$ and/or Ti additions to molten $\mathrm{Fe}$ with constant total oxygen concentration. They reported that $\mathrm{Al}_{2} \mathrm{O}_{3}$ inclusions were formed at first after $\mathrm{Al}$ and $\mathrm{Ti}$ additions, followed by $\mathrm{Ti}$ oxide formation on the existing particles. The latter were then reduced by [Al], resulting in a change of particle morphology from spherical inclusions formed immediately after Al deoxidation to polygonal inclusions.

Park et al. ${ }^{1)}$ studied the reoxidation of Al-Ti containing steel in the tundish by $\mathrm{CaO}-\mathrm{Al}_{2} \mathrm{O}_{3}-\mathrm{MgO}-\mathrm{SiO}_{2}$ slag at $1550^{\circ} \mathrm{C}$ with an initial [Al] of $820 \mathrm{ppm}$ and [Ti] varying from 100 to $500 \mathrm{ppm}$. They observed that [Al] and [Ti] were simultaneously oxidized by $\mathrm{SiO}_{2}$ from the slag, and that dissolved oxygen was supersaturated with respect to the $\mathrm{Al}-\mathrm{O}-\mathrm{Al}_{2} \mathrm{O}_{3}$ equilibrium. The oxygen supersaturation caused the formation of inclusions with a two-layer complex structure, consisting of an $\mathrm{Al}_{2} \mathrm{O}_{3}$ core surrounded by 


\section{Al-Ti-O oxides.}

In the present study, $\mathrm{Al} / \mathrm{Ti}$ and $\mathrm{Al} / \mathrm{Ti} / \mathrm{Al}$ deoxidation experiments are carried out under Ar atmosphere at secondary steelmaking temperatures $\left(1600-1650^{\circ} \mathrm{C}\right)$ in an induction furnace equipped with an oxygen probe and a steel sampler. The influences of the amount of Ti addition and the oxygen level in liquid steel prior to $\mathrm{Ti}$ alloying on the formation mechanism of complex Al-Ti-O inclusions are highlighted in association with inclusion composition and compared with thermodynamic calculations. The purpose is to simulate the influence of locally high [O] and high [Ti] in the ladle on the type and chemistry of inclusions. The subsequent reduction of Ti-containing inclusions through a second $\mathrm{Al}$ addition was evaluated in order to investigate how the Ti recovery can be maximized. Special attention is given to inclusion size, and the compositional correlation between inclusion and steel.

\section{Experimental}

\subsection{Experimental Set-up and Procedures}

The experiments were performed in a vacuum induction furnace (type VSG $30,60 \mathrm{~kW}$ power supply and $4 \mathrm{kHz}$ frequency). A schematic diagram of the experimental set-up is shown in Fig. 1. A loading chamber, a sampling device and a measurement tool are fitted on the furnace lid to allow $\mathrm{Al}$ and $\mathrm{Ti}$ additions, sampling, and oxygen and temperature measurements. Information on the $\mathrm{O}$ and $\mathrm{Ti}$ alloying levels are listed in Table 1. Twenty kilograms of electrolytic iron

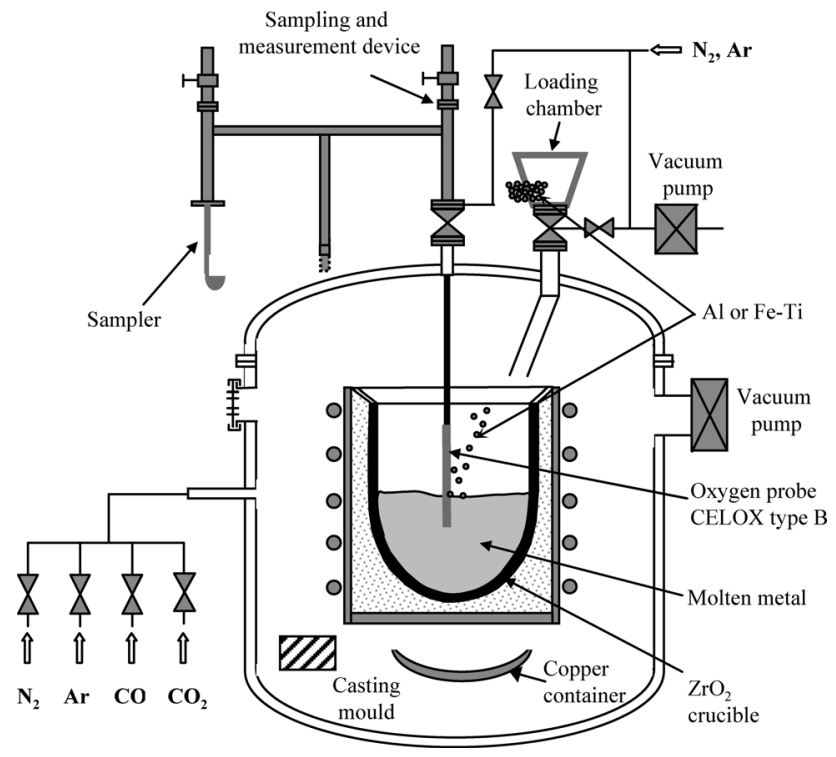

Fig. 1. Schematic diagram of the vacuum induction furnace used in the deoxidation experiments.

Table 1. Oxygen activities (ppm) prior and after Al-deoxidation (measured with Celox probes) and total Ti alloying level (ppm). Values with * are corrected for reoxidation of the steel.

\begin{tabular}{ccccc}
\hline Exp. & $\begin{array}{c}\text { Initial } \\
a_{[O]}\end{array}$ & $\begin{array}{c}a_{[O]} \text { after first } \\
\text { Al deoxidation }\end{array}$ & $\begin{array}{c}a_{[O]} \text { after second } \\
\text { Al deoxidation }\end{array}$ & $\begin{array}{c}\text { Amount of Ti } \\
\text { addition }\end{array}$ \\
\hline 1 & 817 & 1.5 & - & \\
2 & 1265 & $224^{*}$ & 16 & 525 \\
3 & 661 & $138^{*}$ & 11 & \\
4 & 868 & $277^{*}$ & 7.4 & 1500 \\
\hline 5 & 631 & 2.8 & 2.5 & \\
\hline
\end{tabular}

(99.98\% purity) was melted in a zirconia crucible (inner diameter $=150 \mathrm{~mm}$, outer diameter $=176 \mathrm{~mm}$, height $=275$ $\mathrm{mm}$ ) under $\mathrm{Ar}$ atmosphere (99.998\% $\mathrm{Ar}, \mathrm{O}_{2}<5 \mathrm{ppm}$, $\mathrm{N}_{2}<10$ ppm, 500 mbar). After the iron was fully liquid, the temperature was controlled at around 1600 to $1650^{\circ} \mathrm{C}$. $\left.{ }^{9}\right)$ Thereafter, the dissolved oxygen content $\left(a_{[\mathrm{O}]}\right)$ and the temperature of the liquid $\mathrm{Fe}$ were measured with oxygen probes. Except for Exp. 2, the initial $a_{[\mathrm{O}]}$ in the liquid steel ranged from 630 to $870 \mathrm{ppm}$. Subsequently, a steel sample (conical shape, size: upper diameter $=\sim 20 \mathrm{~mm}$, lower diameter $=\sim 10 \mathrm{~mm}$, height $=16-25 \mathrm{~mm}$ ) was taken by dipping the spoon sampler in the liquid bath and rapidly withdrawing it. The steel sample cooled down within a few minutes. Depending on the initial $a_{[\mathrm{O}]}$ and the desired deoxidation level (Table 1) of the liquid steel, a certain amount of granulated pure $\mathrm{Al}$ was added to the liquid steel through the loading chamber. Approximately 2 min later, a sample of the Al-killed steel was taken, instantly followed by a temperature and $a_{[\mathrm{O}]}$ measurement. Ti alloying was performed by adding $\mathrm{Fe}-70 \mathrm{wt} \% \mathrm{Ti}$ alloy to the Al-killed steel through the loading chamber. Except for Exp. 5, the total Ti content was aimed at $525 \mathrm{ppm}$ (Table 1). To investigate the influence of [Ti], the latter was increased to $1500 \mathrm{ppm}$ in Exp. 5. Ti alloying was immediately followed by one or several samplings and temperature- $a_{[\mathrm{O}]}$ measurements. For Exp. 2, 3 and 4, a second $\mathrm{Al}$ addition was performed, followed by sampling and temperature- $a_{[\mathrm{O}]}$ measurements of the melt. At the end of the experiment, the crucible was tilted and the melt was poured into the mould.

\subsection{Characterization of Inclusions}

The steel samples taken during the tests were cut in two parts. One half was prepared for microscopical investigation. The specimens were embedded in a low viscosity resin (Epofix) by vacuum impregnation, grinded with diamond plates and polished with diamond paste. Characterization of the inclusions (size, shape and composition) was conducted with a high resolution scanning electron microscope (Philips SEM XL-30 FEG), equipped with an EDAX energy dispersive spectrometer (EDS) detector system with an ultra thin window. The maximum working magnification was set to 5000 and the effective minimum detectable inclusion size was about $0.5 \mu \mathrm{m}$. For each sample, an area of around $0.15 \mathrm{~mm}^{2}$ was observed to obtain inclusion size and morphology. At least 25 inclusions were analysed for inclusion chemistry. Inclusion and cluster size were defined by, respectively, the maximum length of the sectioned particle and the diameter of the circle comprising the sectioned cluster.

\subsection{Chemical Analysis and Oxygen Determination}

The other half of the steel sample was used for chemical analysis with inductively coupled plasma atomic emission spectroscopy (ICP-AES, Varian Liberty series II instrument with an axial plasma configuration). One gram-steel samples were dissolved in a mixture of acid $\left(\mathrm{H}_{2} \mathrm{O}: \mathrm{HCl}\right.$ : $\left.\mathrm{HNO}_{3}=10: 10: 1\right)$ to bring into solution the acid soluble $\mathrm{Al}$ and $\mathrm{Ti}$, while the insoluble fraction was recovered on a filtration membrane (not further analysed). The solution was analysed with ICP-AES to obtain [Al] and [Ti]. The standard solutions and blanks were prepared with the same acid 
concentrations as those of the sample solutions. $a_{[\mathrm{O}]}$ and temperature of the liquid steel were on-line measured by the intermittent immersion of single-use oxygen probes (Celox type B, provided by Heraeus Electro-Nite). The data were collected by a Multi-Lab III Celox instrument (v3.01). At $1600^{\circ} \mathrm{C}$, the lowest analytical limit and the accuracy of $\mathrm{O}$ probe measurements are, respectively, about $10^{-5} \mathrm{ppm}$ and $0.04 \mathrm{ppm}$.

\section{Results and Discussion}

The sampling moment, [Al], [Ti], $a_{[\mathrm{O}]}$ and the corresponding $\mathrm{Al}$ and $\mathrm{Ti}$ contents of the $\mathrm{Ti}-\mathrm{Al}-\mathrm{O}$ inclusions in the samples are summarized in Table 2. The symbols ( $)_{c}$ and ( ) refer to, respectively, the concentrations in clusters and in single particles.

\subsection{Compositional Evolution of Metal and Inclusions during $\mathrm{Al} / \mathrm{Ti}$ and $\mathrm{Al} / \mathrm{Ti} / \mathrm{Al}$ Deoxidation}

\subsubsection{Al/Ti Deoxidation}

Changes in [Al], [Ti] and $a_{[\mathrm{O}]}$ during Al-Ti deoxidation as a function of time after Al deoxidation for Exp. 1 are shown in Fig. 2. With Al addition, the liquid steel was rapidly deoxidized from an initial $a_{[\mathrm{O}]}$ level of 817 to $1.5 \mathrm{ppm}$. Thereafter, $a_{[\mathrm{O}]}$ remained constant at this low level until the completion of the experiment. There was no decrease in $a_{[\mathrm{O}]}$ after Ti addition. With Ti alloying (aimed at $525 \mathrm{ppm}$ ), the [Ti] reached a level of approximately $505 \mathrm{ppm}$. Thereafter, it remained almost constant (see Table 2). Only $45 \mathrm{ppm}$ [Ti] was lost after holding the melt for $60 \mathrm{~min}$ in the crucible without top slag coverage. This confirms that Ti can be efficiently alloyed into the liquid steel after a strong Al deoxidation. On the other hand, the [Al] gradually decreased with time, as a result of [Al] oxidation through reaction with the residual oxygen in the Ar gas flow. Considering the metal composition changes with time for every test, the reoxidation rate of the melt is evaluated at approximately $20 \mathrm{ppm} / \mathrm{min}$. Only pure $\mathrm{Al}_{2} \mathrm{O}_{3}$ inclusions were observed in the metal samples taken after Ti alloying (Table 3).

\subsection{2. $\mathrm{Al} / \mathrm{Ti} / \mathrm{Al}$ Deoxidation}

Figure 3 shows the evolutions of [Al], [Ti], $a_{[\mathrm{O}]}$ and the $(\mathrm{Ti})_{\mathrm{s}} /(\mathrm{Al})_{\mathrm{s}}$ ratio in the $\mathrm{Ti}-\mathrm{Al}-\mathrm{O}$ inclusions as a function of time after the first $\mathrm{Al}$ addition for Exp. 2. The purpose of this test was to perform a partial deoxidation of the steel with the first $\mathrm{Al}$ addition, followed by Ti alloying and a second $\mathrm{Al}$ addition. As seen in the upper diagram of Fig. 3, $a_{[\mathrm{O}]}$ was controlled at $64 \mathrm{ppm}$ by the first $\mathrm{Al}$ addition. $a_{[\mathrm{O}]}$ at the moment of the Ti addition was corrected to $224 \mathrm{ppm}$ to take into account steel reoxidation during the $8 \mathrm{~min}$ between the oxygen measurement and the Ti addition. It was further reduced to 22 and $16 \mathrm{ppm}$ with, respectively, Ti alloying (aimed at $525 \mathrm{ppm}$ ) and a second $\mathrm{Al}$ addition. The former suggests that part of the added Ti was consumed through $\mathrm{Ti}$ deoxidation. This is confirmed by analyses of the inclusion composition. The ratio $(\mathrm{Ti})_{\mathrm{s}} /(\mathrm{Al})_{\mathrm{s}}$ in the small randomly dispersed inclusions drastically increased after $\mathrm{Ti}$ addition (lower diagram of Fig. 3), while only 78 ppm [Ti] was obtained in the bulk metal immediately after Ti addition, indicating the occurrence of Ti deoxidation. After the
Table 2. Chemical composition of liquid steel and that of inclusions. $t_{\mathrm{A} 11}, t_{\mathrm{Ti}}$ and $t_{\mathrm{Al} 2}$ represent, respectively, the time after first $\mathrm{Al}$ addition, $\mathrm{Ti}$ addition and second $\mathrm{Al}$ addition. $a_{[\mathrm{O}]}$ was measured with Celox probes. * indicates modified $a_{[\mathrm{O}]}$ values considering the reoxidation rate of the steel. [Al] and [Ti] were obtained with ICP-AES. The inclusion composition was determined by EDS analysis. ( ) and ( ) refer to the content in clusters and in single particles.

\begin{tabular}{|c|c|c|c|c|c|c|c|c|c|c|}
\hline \multirow{2}{*}{ Sample } & \multicolumn{3}{|c|}{ Time $(\min )$} & \multicolumn{3}{|c|}{ Steel composition (ppm) } & \multicolumn{4}{|c|}{ Inclusion composition (at \%) } \\
\hline & $t_{A l l}$ & $t_{T i}$ & $t_{A 12}$ & $a_{[O]}$ & {$[\mathrm{Al}]$} & {$[\mathrm{Ti}]$} & $(\mathrm{Ti})_{\mathrm{c}}$ & $(\mathrm{Al})_{\mathrm{c}}$ & $(\mathrm{Ti})_{\mathrm{s}}$ & $(\mathrm{Al})_{\mathrm{s}}$ \\
\hline $1 \mathrm{~A}$ & 3 & & - & 1.5 & 2000 & - & - & 86.4 & - & - \\
\hline 1B & 6 & 2 & - & 1.5 & 1912 & 505 & - & 72.7 & - & - \\
\hline $1 \mathrm{C}$ & & 14 & - & 1.3 & 1649 & 488 & - & 90.7 & - & - \\
\hline $1 \mathrm{D}$ & & 19 & - & 1.3 & 1495 & 453 & - & 85.8 & - & - \\
\hline $1 \mathrm{E}$ & & 57 & - & 2.8 & 949 & 460 & - & - & - & - \\
\hline $2 \mathrm{~A} 0$ & 1 & & & 17 & 420 & 0 & - & - & - & - \\
\hline $2 \mathrm{~A}$ & 22 & & & $224 *$ & 2 & 0 & 0 & 82.8 & 0 & 15.8 \\
\hline $2 \mathrm{~B}$ & 28 & 1 & & 22 & 1 & 78 & 1.15 & 90.4 & 58.0 & 9.93 \\
\hline $2 \mathrm{C}$ & & 12 & & 20 & 32 & 67 & 16.2 & 69.9 & 43.0 & 5.23 \\
\hline $2 \mathrm{D}$ & & 14 & 1 & 16 & 537 & 304 & 0.53 & 75.3 & 22.0 & 21.6 \\
\hline $2 \mathrm{E}$ & & & 11 & 17 & 283 & 347 & - & - & 22.7 & 21.3 \\
\hline $3 \mathrm{~A}$ & 2 & & & $138^{*}$ & 23 & 0 & 0 & 67.5 & 0 & 9.00 \\
\hline $3 \mathrm{~B}$ & 8 & 3 & & 23 & 18 & 255 & 7.8 & 73.3 & 18.7 & 8.70 \\
\hline $3 \mathrm{C}$ & & 11 & & 39 & 16 & 54 & 18.6 & 59.3 & 32.4 & 8.20 \\
\hline $3 \mathrm{D}$ & & 20 & & 79 & 4 & 7 & - & - & 4.60 & 1.51 \\
\hline $3 \mathrm{E}$ & & 81 & 3 & 10.8 & 634 & 118 & 0.28 & 52.8 & 2.04 & 22.7 \\
\hline $3 \mathrm{~F}$ & & & 17 & 11.1 & 367 & 153 & - & - & 7.80 & 24.3 \\
\hline $4 \mathrm{~A}$ & 4 & & & $277^{*}$ & 21 & 0 & 0.22 & 72.6 & 0.28 & 10.4 \\
\hline $4 B$ & 30 & 1 & & 45 & 1 & 52 & 12.8 & 69.6 & 51.3 & 9.1 \\
\hline $4 C$ & & 20 & 2 & 7.4 & 623 & 184 & 0.51 & 78.9 & 3.1 & 9.0 \\
\hline $4 \mathrm{D}$ & & & 10 & 10.6 & 468 & 254 & 0.43 & 78.0 & 6.1 & 22.0 \\
\hline $4 \mathrm{E}$ & & & 18 & 13 & 346 & 294 & 0.88 & 80.9 & 8.6 & 27.5 \\
\hline $5 \mathrm{~A}$ & 2 & & & 2.8 & 1894 & 0 & 0 & 92.7 & 0 & 71.8 \\
\hline $5 \mathrm{~B}$ & 9 & 1 & & 2.5 & 1803 & 828 & 0 & 78.3 & 4.10 & 29.8 \\
\hline $5 \mathrm{C}$ & & 23 & & 2.5 & 1266 & 808 & 0 & 78.4 & 14.2 & 28.3 \\
\hline $5 \mathrm{D}$ & & 29 & 3 & 2.5 & 1808 & 866 & 0 & 69.8 & 4.41 & 13.5 \\
\hline $5 \mathrm{E}$ & & & 20 & 2.1 & 1733 & 900 & - & - & 5.54 & 17.1 \\
\hline
\end{tabular}

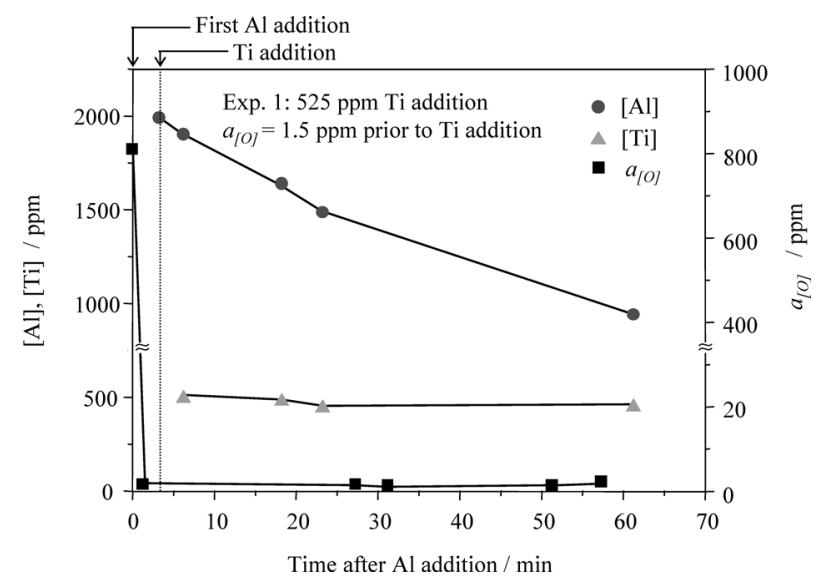

Fig. 2. Evolution of [Al], [Ti] and $a_{[\mathrm{O}]}$ in liquid steel after $\mathrm{Al}-\mathrm{Ti}$ deoxidation (Exp. 1).

second $\mathrm{Al}$ addition, $a_{[\mathrm{O}]}$ is still relatively high (upper diagram of Fig. 3, $a_{[\mathrm{O}]}=16 \mathrm{ppm}$ ), substantiating the findings by Kunisada et al. $^{5 \text { ) }}$ that $\mathrm{Ti} / \mathrm{Al}$ deoxidation was less efficient than single Al deoxidation. With the second Al addition, [Ti] rose abruptly. Afterwards, it increased moderately with time. Meanwhile [Al] decreases. Apparently, Ti containing oxides formed during Ti alloying were reduced after the second $\mathrm{Al}$ addition, the reduction proceeding fast at the be- 
Table 3. Inclusion type and dimensions (in $\mu \mathrm{m}$ ) in the samples. $t_{\mathrm{Al} 1}, t_{\mathrm{Ti}}$ and $t_{\mathrm{Al} 2}$ represent, respectively, the time after first $\mathrm{Al}$ addition, Ti addition and second $\mathrm{Al}$ addition. $d_{\text {mean }}, d_{\max }$ and $d_{\min }$ are respectively the mean, maximum and minimum diameters of the inclusions.

\begin{tabular}{|c|c|c|c|c|c|c|c|c|c|c|c|c|c|}
\hline \multirow[t]{2}{*}{ Sample } & \multicolumn{3}{|c|}{ Time (min) } & \multicolumn{3}{|c|}{ Cluster } & \multicolumn{3}{|c|}{$\begin{array}{l}\text { Single particle } \\
\text { within clusters }\end{array}$} & \multicolumn{3}{|c|}{$\begin{array}{l}\text { Random distributed } \\
\text { single particles }\end{array}$} & \multirow[t]{2}{*}{ Type of inclusions } \\
\hline & $t_{A l I}$ & $t_{T i}$ & $t_{A 12}$ & $d_{\text {mean }}$ & $d_{\max }$ & $d_{\min }$ & $d_{\text {mean }}$ & $d_{\max }$ & $d_{\min }$ & $d_{\text {mean }}$ & $d_{\max }$ & $d_{\min }$ & \\
\hline $1 \mathrm{~A}$ & 3 & & - & - & - & - & 3.81 & 6.96 & 1.39 & - & - & - & $\mathrm{Al}_{2} \mathrm{O}_{3}$ cluster \\
\hline 1B & 6 & 2 & - & 891 & 1580 & 487 & 4.26 & 16.9 & 1.22 & - & - & - & $\mathrm{Al}_{2} \mathrm{O}_{3}$ cluster \\
\hline $1 \mathrm{C}$ & & 14 & - & 836 & 1060 & 515 & 2.67 & 8.71 & 1.13 & 0.78 & 0.94 & 0.52 & $\mathrm{Al}_{2} \mathrm{O}_{3}$ cluster \\
\hline $1 \mathrm{D}$ & & 19 & - & 921 & 1580 & 414 & 2.57 & 6.79 & 1.04 & 1.16 & 1.23 & 1.08 & $\mathrm{Al}_{2} \mathrm{O}_{3}$ cluster \\
\hline $1 \mathrm{E}$ & & 57 & - & - & - & - & - & - & - & - & - & - & $\mathrm{Al}_{2} \mathrm{O}_{3}$ cluster \\
\hline $2 \mathrm{~A}$ & 22 & & & 977 & 2160 & 109 & 3.52 & 7.66 & 1.22 & 1.80 & 2.51 & 1.18 & $\begin{array}{l}\mathrm{Al}_{2} \mathrm{O}_{3} \text { cluster }+ \text { small } \\
\text { spherical } \mathrm{Al}_{2} \mathrm{O}_{3}\end{array}$ \\
\hline $2 \mathrm{~B}$ & 28 & 1 & & 1060 & 3500 & 195 & 3.36 & 10.1 & 0.70 & 2.53 & 3.66 & 1.60 & $\begin{array}{l}\mathrm{Al}_{2}(\mathrm{Ti}) \mathrm{O}_{3} \text { cluster }+ \text { small } \\
\text { Ti-Al oxides }\end{array}$ \\
\hline $2 \mathrm{C}$ & & 12 & & 1155 & 2980 & 403 & 3.44 & 8.79 & 1.57 & 1.47 & 2.40 & 0.61 & $\begin{array}{l}\mathrm{Al}_{2}(\mathrm{Ti}) \mathrm{O}_{3} \text { cluster }+ \text { small } \\
\text { Ti-Al oxides }\end{array}$ \\
\hline $2 \mathrm{D}$ & & 14 & 1 & 2158 & 8000 & 230 & 4.39 & 11.5 & 1.39 & 2.11 & 3.45 & 0.91 & $\begin{array}{l}\text { large } \mathrm{Al}_{2} \mathrm{O}_{3} \text { cluster }+ \text { few } \\
\text { small } \mathrm{Ti}-\mathrm{Al} \text { oxides }\end{array}$ \\
\hline $2 \mathrm{E}$ & & & 11 & - & - & - & - & - & - & - & - & - & $\mathrm{Al}_{2} \mathrm{O}_{3}$ cluster \\
\hline $3 \mathrm{~A}$ & 2 & & & 52 & 174 & 20 & 2.56 & 4.35 & 0.87 & 1.83 & 4.09 & 0.78 & $\mathrm{Al}_{2} \mathrm{O}_{3}$ cluster \\
\hline $3 \mathrm{~B}$ & 8 & 3 & & 426 & 670 & 181 & - & - & - & 1.33 & 3.13 & 0.70 & $\begin{array}{l}\mathrm{Al}_{2}(\mathrm{Ti}) \mathrm{O}_{3} \text { cluster }+ \text { small } \\
\mathrm{Ti}-\mathrm{Al} \text { oxides }\end{array}$ \\
\hline $3 \mathrm{C}$ & & 11 & & 1562 & 3250 & 635 & 3.10 & 10.3 & 1.22 & 1.20 & 2.70 & 0.44 & $\begin{array}{l}\text { large } \mathrm{Al}_{2} \mathrm{O}_{3} \text { clusters }+ \text { small } \\
\text { Ti-Al oxides }\end{array}$ \\
\hline $3 \mathrm{D}$ & & 20 & & - & - & - & - & - & - & 0.97 & 1.92 & 0.45 & $\begin{array}{l}\text { large } \mathrm{Al}_{2} \mathrm{O}_{3} \text { clusters }+ \text { small } \\
\text { Ti-Al oxides }\end{array}$ \\
\hline $3 \mathrm{E}$ & & 81 & 3 & 360 & 1120 & 68 & 2.77 & 7.40 & 1.04 & 1.48 & 2.12 & 0.61 & $\mathrm{Al}_{2} \mathrm{O}_{3}$ cluster \\
\hline $3 \mathrm{~F}$ & & & 17 & - & - & - & - & - & - & - & - & - & - \\
\hline $4 \mathrm{~A}$ & 4 & & & 652 & 1890 & 237 & 2.21 & 5.40 & 0.70 & 1.66 & 3.22 & 0.78 & $\begin{array}{l}\mathrm{Al}_{2} \mathrm{O}_{3} \text { cluster }+ \text { small } \mathrm{Al}-\mathrm{Si} \\
\text { oxides }\end{array}$ \\
\hline $4 \mathrm{~B}$ & 30 & 1 & & 1100 & 1950 & 433 & 4.03 & 15.1 & 1.04 & 2.08 & 9.40 & 0.96 & $\begin{array}{l}\mathrm{Al}_{2}(\mathrm{Ti}) \mathrm{O}_{3} \text { cluster }+ \text { small } \\
\text { Ti-Al oxides }\end{array}$ \\
\hline $4 \mathrm{C}$ & & 20 & 2 & 486 & 1320 & 240 & 2.34 & 4.44 & 0.96 & 1.49 & 2.96 & 0.31 & $\begin{array}{l}\mathrm{Al}_{2} \mathrm{O}_{3} \text { cluster }+ \text { small Ti-Al } \\
\text { oxides }\end{array}$ \\
\hline $4 \mathrm{D}$ & & & 10 & 414 & 795 & 127 & 2.55 & 5.48 & 0.52 & 1.89 & 3.31 & 1.13 & $\begin{array}{l}\mathrm{Al}_{2} \mathrm{O}_{3} \text { cluster }+ \text { few small } \\
\mathrm{Ti}-\mathrm{Al} \text { oxides }\end{array}$ \\
\hline $4 \mathrm{E}$ & & & 18 & - & - & - & 3.31 & 6.27 & 1.22 & 1.77 & 3.57 & 0.63 & $\begin{array}{l}\text { few } \mathrm{Al}_{2} \mathrm{O}_{3} \text { cluster }+ \text { few } \\
\text { small Ti-Al oxides }\end{array}$ \\
\hline $5 \mathrm{~A}$ & 2 & & & 776 & 2810 & 20 & 2.52 & 4.79 & 0.87 & 1.31 & 3.57 & 0.44 & $\begin{array}{l}\mathrm{Al}_{2} \mathrm{O}_{3} \text { cluster }+ \text { small } \\
\text { spherical } \mathrm{Al}_{2} \mathrm{O}_{3}\end{array}$ \\
\hline $5 B$ & 9 & 1 & & 1232 & 4060 & 162 & 2.64 & 11.1 & 0.87 & 1.06 & 1.46 & 0.73 & $\begin{array}{l}\mathrm{Al}_{2} \mathrm{O}_{3} \text { cluster }+ \text { few small } \\
\text { spherical Ti-Al oxides }\end{array}$ \\
\hline $5 \mathrm{C}$ & & 23 & & 1528 & 2860 & 411 & 3.69 & 11.30 & 1.31 & 1.27 & 2.86 & 0.80 & $\begin{array}{l}\mathrm{Al}_{2} \mathrm{O}_{3} \text { cluster }+ \text { few small } \\
\text { spherical Ti-Al oxides }\end{array}$ \\
\hline $5 \mathrm{D}$ & & 29 & 3 & 3475 & 3560 & 3390 & 3.53 & 7.49 & 1.74 & 0.95 & 2.33 & 0.49 & $\begin{array}{l}\mathrm{Al}_{2} \mathrm{O}_{3} \text { cluster }+ \text { few small } \\
\text { spherical Ti-Al oxides with } \\
\text { TiN overgrowth - }\end{array}$ \\
\hline $5 \mathrm{E}$ & & & 20 & - & - & - & - & - & - & 0.74 & 1.08 & 0.21 & $\begin{array}{l}\mathrm{Al}_{2} \mathrm{O}_{3} \text { cluster }+ \text { small } \\
\text { spherical } \mathrm{Al}_{2} \mathrm{O}_{3}\end{array}$ \\
\hline
\end{tabular}

ginning. The $(\mathrm{Ti})_{\mathrm{s}} /(\mathrm{Al})_{\mathrm{s}}$ ratio in the $\mathrm{Ti}-\mathrm{Al}-\mathrm{O}$ inclusions dropped rapidly from around 8 to 1 within $1 \mathrm{~min}$ after the second $\mathrm{Al}$ addition, and remained constant at $(\mathrm{Ti})_{\mathrm{s}} /(\mathrm{Al})_{\mathrm{s}}=1$ (lower diagram of Fig. 3). A fraction of Ti was inevitably lost during the alloying process since Ti containing oxides could not be completely reduced with the second $\mathrm{Al}$ addition under the present test conditions.

\subsection{Characteristics of $\mathbf{A l} / \mathbf{T i}$ and $\mathrm{Al} / \mathrm{Ti} / \mathrm{Al}$ Deoxidation Products}

3.2.1. Overview of Inclusions Formed during Deoxidation

Per sample the following information is provided in Table 3: (1) sampling moment $\left(_{\mathrm{Al} 1}, t_{\mathrm{Ti}}\right.$ and $t_{\mathrm{Al} 2}$ are respectively the holding times after first $\mathrm{Al}$ addition, $\mathrm{Ti}$ addition and second $\mathrm{Al}$ addition), (2) inclusion size ( $d_{\text {mean }}, d_{\max }$ and $d_{\min }$ are respectively the mean, maximum and minimum diameters for complete cluster, single particle within a cluster, and single particles randomly distributed in the steel matrix) and (3) type of inclusions. Prior to Ti alloying, only $\mathrm{Al}_{2} \mathrm{O}_{3}$ inclusions, mainly present as clusters, were found.
After the Ti addition, the inclusions can be roughly categorized into two types: large $\mathrm{Al}_{2} \mathrm{O}_{3}$ clusters (Fig. 4(a)) and small Ti-Al oxide particles (Fig. 4(b)). The latter are randomly distributed in the steel matrix. These small particles consist of a Ti-Al-O core with $\mathrm{Al}_{2} \mathrm{O}_{3}$ overgrowth (Fig. 4(b)). In some samples taken immediately after Ti alloying (2B, 3B and $4 \mathrm{~B})$, several Ti oxide particles were detected in the $\mathrm{Al}_{2} \mathrm{O}_{3}$ clusters (Fig. 4(c)). After the second $\mathrm{Al}$ addition, only $\mathrm{Al}_{2} \mathrm{O}_{3}$ clusters and a limited amount of small $\mathrm{Al}-\mathrm{Ti}-\mathrm{O}$ inclusions were found in the samples, owing to the reduction of $\mathrm{Al}-\mathrm{Ti}-\mathrm{O}$ inclusions by $\mathrm{Al}$ addition. Few cubic TiN particles with Al-Ti oxide core, formed through reaction with residual $\mathrm{N}_{2}$ in the Ar gas flow, were observed below the sample surface in Exp. 5 in which Ti alloying level was raised to $1500 \mathrm{ppm}$ (Fig. 4(d)). Based on Thermo-Calc predictions, Van der Eijk et al. ${ }^{10)}$ pointed out that the TiN formation probably occurs through an exchange reaction with $\mathrm{Ti}_{2} \mathrm{O}_{3}$ (or $\mathrm{Ti}_{3} \mathrm{O}_{5}$ ) in the solid state. No evidence indicating the existence of a liquid Al-Ti-O phase was found during the SEM observations. An extremely fast quenching of the 
sample may be required to be assured about the liquid or solid state of the Al-Ti-O inclusions at steelmaking temperature.

\subsubsection{Inclusion Size}

The average size of single $\mathrm{Ti}-\mathrm{Al}-\mathrm{O}$ inclusions varies from 0.75 to $2.5 \mu \mathrm{m}$, while single $\mathrm{Al}_{2} \mathrm{O}_{3}$ particles within the clusters ranged from 2.2 to $4.4 \mu \mathrm{m}$ (Table 3 ). No correlation was found between particle size and time after first $\mathrm{Al}$ deoxidation and/or Ti alloying. Nevertheless, Table 3 shows that the average size of the single Ti-Al-O inclusions is about $2 \mu \mathrm{m}$ smaller than that of the single $\mathrm{Al}_{2} \mathrm{O}_{3}$ particles within clusters. This might be explained by the different levels of supersaturation with respect to the [Al]-[O]-

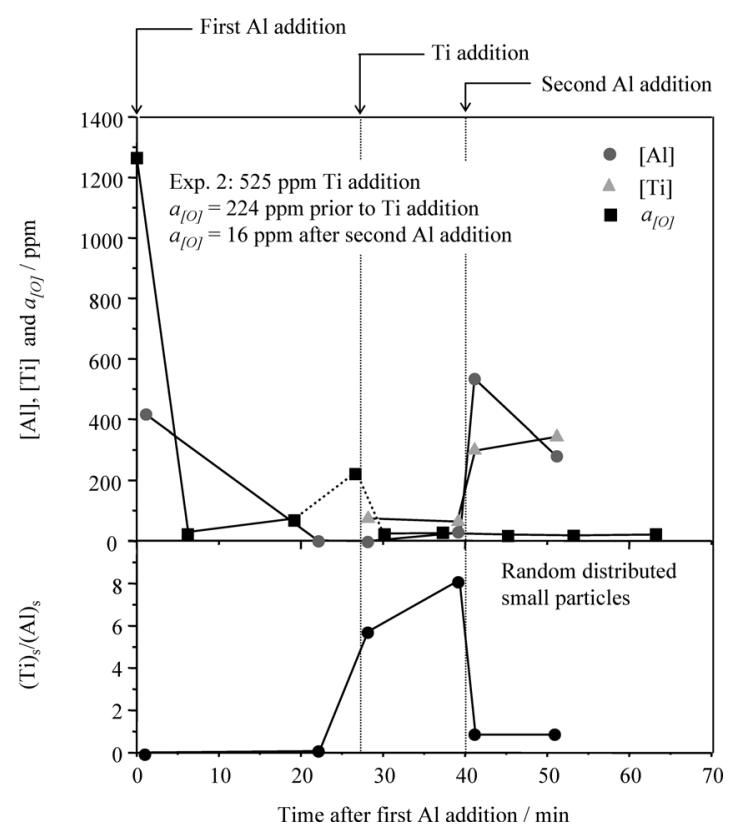

Fig. 3. Changes in [Al], [Ti] and $a_{[0]}$ in liquid steel, and changes in $(\mathrm{Ti})_{\mathrm{s}} /(\mathrm{Al})_{\mathrm{s}}$ ratio in inclusions with time during Al-Ti-Al deoxidation (Exp. 2).
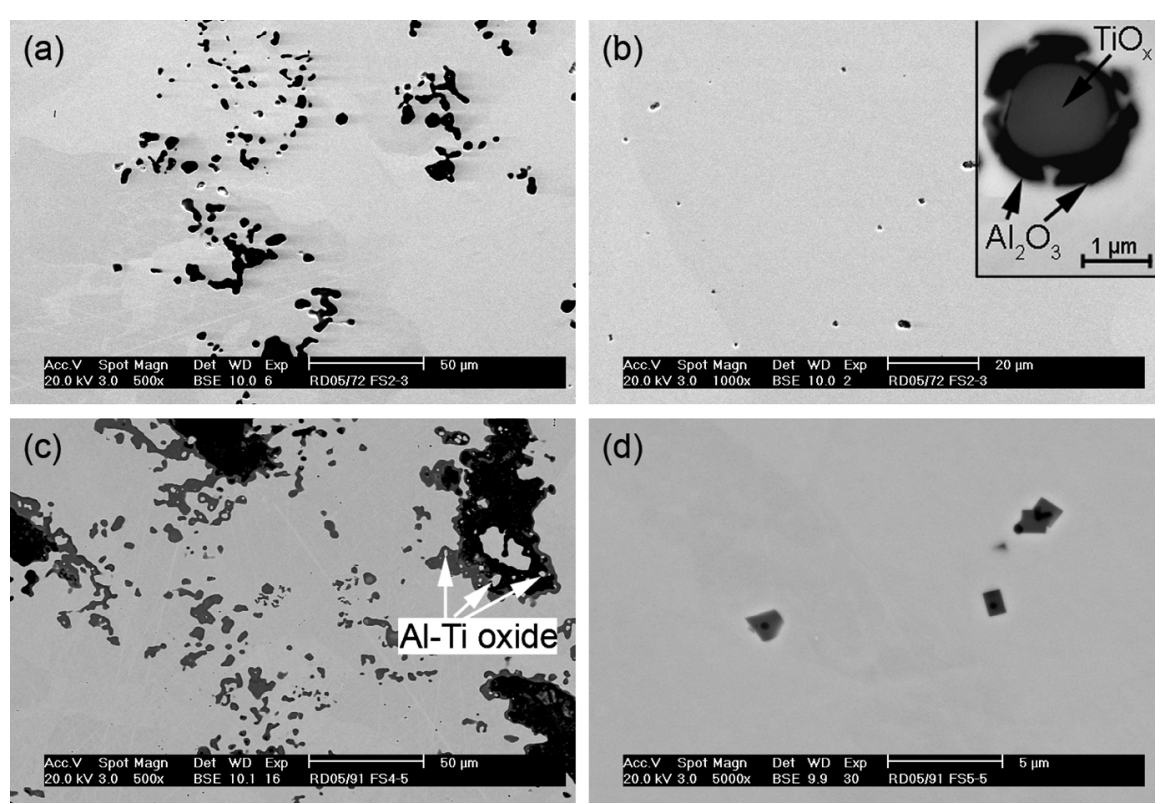

Fig. 4. Types of inclusions observed after Ti alloying: (a) $\mathrm{Al}_{2} \mathrm{O}_{3}$ cluster (3B, 3 min after Ti addition); (b) small Ti-Al-O particles with $\mathrm{Al}_{2} \mathrm{O}_{3}$ overgrowth (3B, 3 min after Ti addition); (c) Al-Ti-O cluster (2C, 12 min after Ti addition); and (d) cubic TiN (5D, 3 min after second $\mathrm{Al}$ addition).
$\mathrm{Al}_{2} \mathrm{O}_{3}(\mathrm{~s})$ and [Ti]-[O]- $\mathrm{TiO}_{x}(\mathrm{~s})$ equilibria. For a given [O], [Al] has a much higher supersaturation level with respect to [Ti], ${ }^{1)}$ resulting in a larger driving force for precipitation and growth of $\mathrm{Al}_{2} \mathrm{O}_{3}$ inclusions compared with $\mathrm{TiO}_{x}$ inclusions. The size of the $\mathrm{Al}_{2} \mathrm{O}_{3}$ clusters ranged from $50 \mu \mathrm{m}$ to $1.5 \mathrm{~mm}$. As shown in Fig. 5, the diameter of the cluster increased with time between the first and second $\mathrm{Al}$ addition, due to coalescence of $\mathrm{Al}_{2} \mathrm{O}_{3}$ particles. Collision-coagulation mechanisms, and especially turbulent and Stokes collisions, seem to be the major contributor to inclusion growth under the present conditions.

\subsubsection{Inclusion Composition}

Figure 6 shows the influence of $[\mathrm{Al}]$ on the $(\mathrm{Ti})_{\mathrm{s}} /(\mathrm{Al})_{\mathrm{s}}$ ratio of the inclusions. The $\mathrm{Ti}$ content in the $\mathrm{Ti}-\mathrm{Al}-\mathrm{O}$ inclusions rapidly decreases with increasing [Al]. It can be concluded from these experimental data that more than $300 \mathrm{ppm}[\mathrm{Al}]$ is required to prevent the formation of Ti-oxides during Ti alloying, as a result of low $a_{[\mathrm{O}]}$ in the liquid steel. It is therefore essential to ensure a sufficiently high [Al] value and homogeneity throughout the ladle prior to $\mathrm{Ti}$ addition, to avoid locally low [Al], high $a_{[\mathrm{O}]}$ and high [Ti],

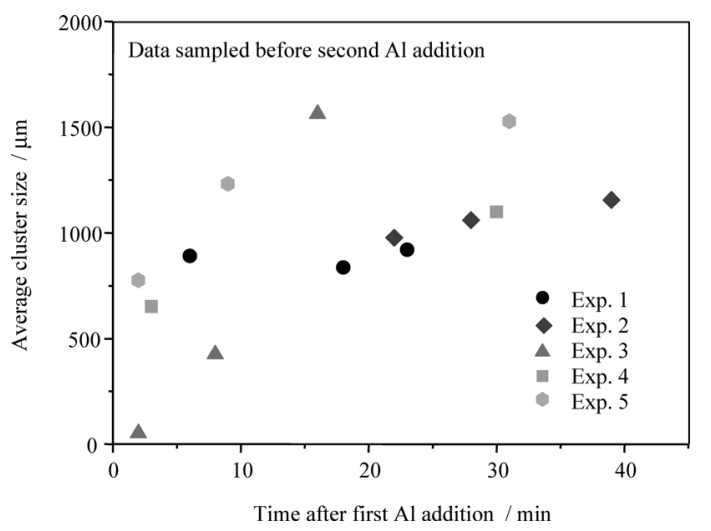

Fig. 5. Evolution of the average cluster size with time after first Al addition. 


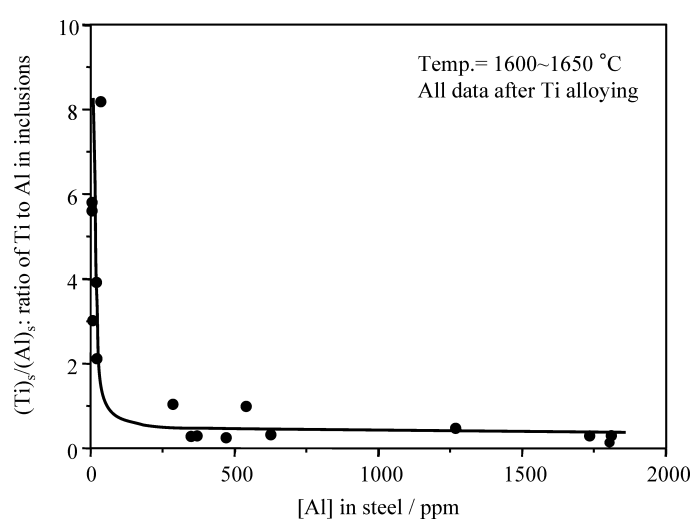

Fig. 6. Correlation between $[\mathrm{Al}]$ and the $(\mathrm{Ti})_{\mathrm{s}} /(\mathrm{Al})_{\mathrm{s}}$ ratio in the Ti-Al-O inclusions.

causing the formation of $\mathrm{Al}-\mathrm{Ti}-\mathrm{O}$ inclusions.

\subsection{Ti Deoxidation during Ti Alloying and Reduction of Ti Containing Inclusions by a Strong Second Al Deoxidation}

\subsubsection{Oxidation of Ti during Ti Alloying}

The influence of $a_{[\mathrm{O}]}$ prior to Ti addition on the oxidation of Ti was investigated by varying $a_{[\mathrm{O}]}$ before Ti alloying. Figure 7 depicts the evolution of [Ti] and [O] in the steel before and after Ti addition for Exp. 1 to 4. [O] prior to Ti addition were adjusted to take into account the reoxidation of the melt occurring between the oxygen measurement and the $\mathrm{Ti}$ addition. In the ideal case, when $\mathrm{Ti}_{3} \mathrm{O}_{5}-[\mathrm{Ti}]-[\mathrm{O}]$ equilibrium would be reached without reoxidation of the melt, the melt composition after Ti addition would correspond to the open markers in Fig. 7. The observed steel composition evolutions during Ti addition for Exp. 1 to 4 are indicated by the arrows and grey markers. The steel composition after $\mathrm{Ti}$ addition tends to the corresponding equilibrium value. However, higher [O] and lower [Ti] are attained compared to the equilibrium composition, suggesting that equilibrium is not reached and/or reoxidation of the melt occurs ( 1 to 2 min elapsed between Ti addition and the next sampling and oxygen measurement). As seen in Fig. 7, the extent of Ti oxidation strongly depends on $a_{[\mathrm{O}]}$ prior to Ti addition. Low $a_{[\mathrm{O}]}$ prior to Ti alloying prevents Ti oxidation during Ti alloying to $525 \mathrm{ppm}$ (Exp. 1), while Ti loss by oxidation increases significantly with $a_{[\mathrm{O}]}$ prior to Ti alloying (Exp. 2, 3 and 4).

With Exp. 5, the $\mathrm{Ti}$ alloying level was raised to $1500 \mathrm{ppm}$ after that low $a_{[\mathrm{O}]}$ was achieved through Al deoxidation, in order to assess whether [Ti] oxidation may be achieved by combining high [Ti] and low $a_{[\mathrm{O}]}$. Although Ticontaining inclusions were found near the sample surface (samples 5B, C and D in Table 3), they have a low Ti content. The $\mathrm{Ti}$ to $\mathrm{Al}$ ratio of the inclusions ranged between 0.1 and 0.5 (Table 2). Raising the Ti alloying level to $1500 \mathrm{ppm}$ had no significant effect on [Ti] oxidation when low $a_{[\mathrm{O}]}$ was maintained.

\subsubsection{Reduction of Ti Containing Inclusions by a Strong Second Al Deoxidation}

Figure 8 shows the changes in $[\mathrm{Al}]$ and [Ti] as a function of time after the second $\mathrm{Al}$ addition. The reduction of $\mathrm{Ti}$ oxides took place efficiently in the beginning of the second

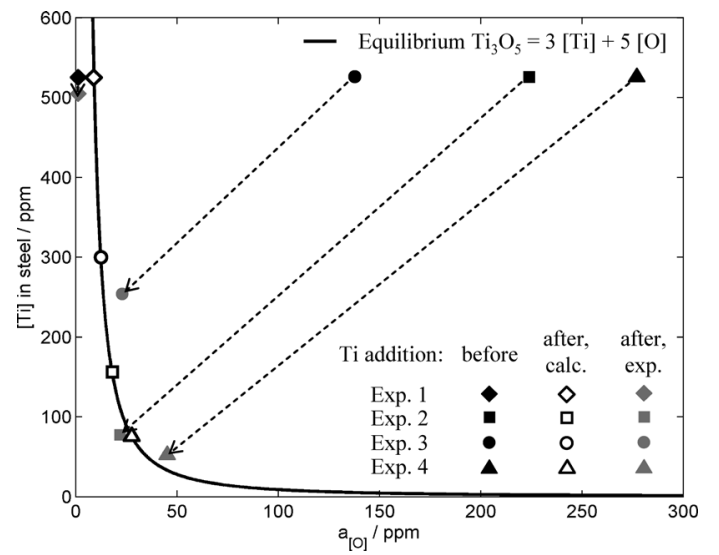

Fig. 7. Relation between [Ti] and $a_{[\mathrm{O}]}$ before and after Ti addition for Exp. 1 to 4. Solid black and solid grey markers correspond to, respectively, the observed melt composition before and after Ti addition. The solid line shows the $\mathrm{Ti}_{3} \mathrm{O}_{5}(\mathrm{~s})-[\mathrm{Ti}]-[\mathrm{O}]$ equilibrium relation at $1620^{\circ} \mathrm{C}$. Open markers indicate the calculated melt compositions after $\mathrm{Ti}$ addition, considering the stoichiometry of the Ti oxidation reaction and assuming that equilibrium is reached.

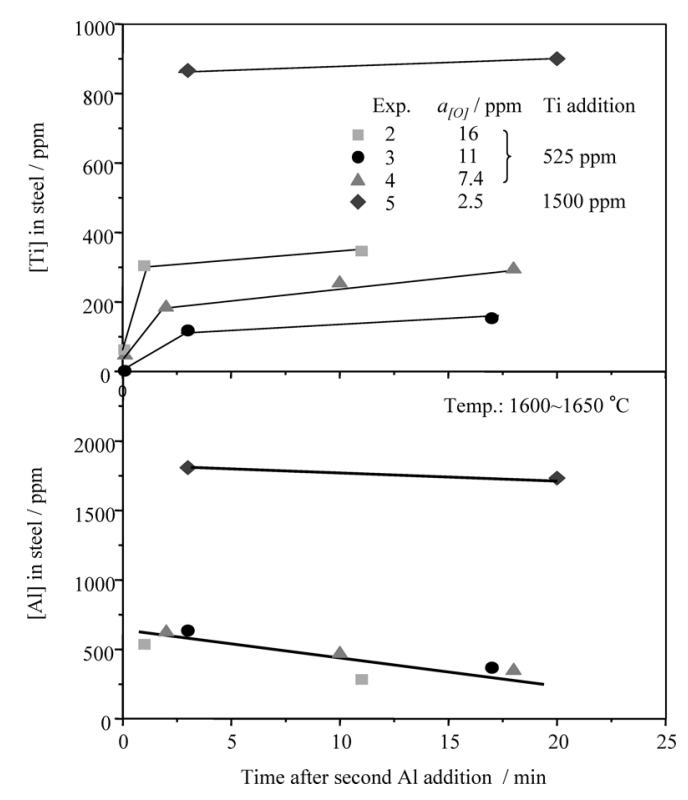

Fig. 8. Changes in $[\mathrm{Al}]$ and $[\mathrm{Ti}]$ with time after second $\mathrm{Al}$ deoxidation.

$\mathrm{Al}$ addition, but the complete recovery of $\mathrm{Ti}$ from $\mathrm{Ti}-\mathrm{Al}-\mathrm{O}$ inclusions took time. The combination of higher Ti addition (1500 ppm) and higher [Al] (Exp. 5) results in a higher [Ti].

The comparison of the results in Fig. 8 with respect to Exp. 2, 3 and 4 indicates that, with identical Ti alloying levels (525 ppm Ti) and similar [Al], distinct [Ti] were achieved after similar second $\mathrm{Al}$ additions. The time between $\mathrm{Ti}$ addition and second $\mathrm{Al}$ addition influences Ti recovery. As shown in Fig. 9, with longer time between Ti addition and second Al addition, lower [Ti] were achieved after the second Al deoxidation. The rise and removal of $\mathrm{Ti}-\mathrm{Al}-\mathrm{O}$ inclusions to the liquid steel surface hinder Ti recovery at longer times. Less $\mathrm{Ti}-\mathrm{Al}-\mathrm{O}$ inclusions were available in the bulk steel to react with [Al] when late second $\mathrm{Al}$ addition was performed. Hence, to improve Ti recovery, Al addition should be made shortly after Ti alloying. 


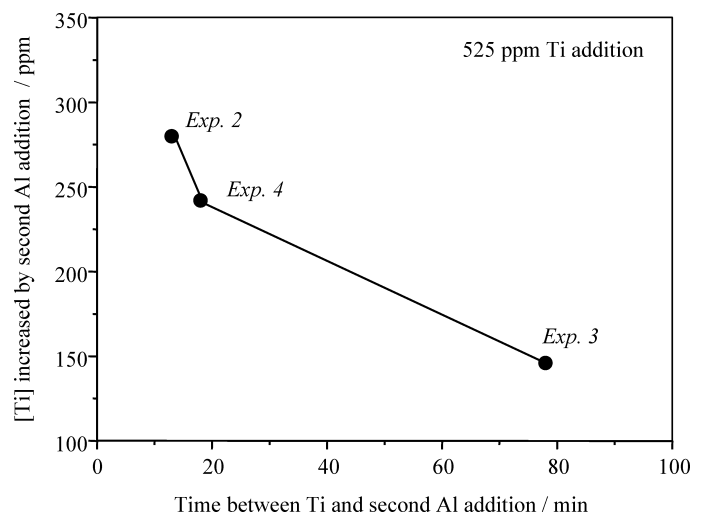

Fig. 9. Relation between the amount of Ti recovered after the second $\mathrm{Al}$ addition and the time between $\mathrm{Ti}$ alloying and the second $\mathrm{Al}$ addition.

\subsection{Thermodynamic Considerations}

\subsubsection{Inclusion Phase Stability}

Ti forms many types of oxide and some of them have large solid solubility. ${ }^{11)}$ When [Ti] and [Al] simultaneously exist in the liquid steel at a given $a_{[\mathrm{O}]}$, equilibrium in the $\mathrm{Fe}(\mathrm{l})-\mathrm{Al}_{2} \mathrm{O}_{3}-\mathrm{TiO}_{x}-\mathrm{AlTiO}_{x}$ system can be expressed by the reactions,

$$
\begin{aligned}
& 2[\mathrm{Ti}]+3[\mathrm{O}]=\mathrm{Ti}_{2} \mathrm{O}_{3}(\mathrm{~s}), \quad \Delta G_{1}^{\circ}=-263000+85.25 T^{12,13)} \\
& 3[\mathrm{Ti}]+5[\mathrm{O}]=\mathrm{Ti}_{3} \mathrm{O}_{5}(\mathrm{~s}), \quad \Delta G_{2}^{\circ}=-424000+136.2 T^{12,13)} \\
& 2[\mathrm{Al}]+3[\mathrm{O}]=\mathrm{Al}_{2} \mathrm{O}_{3}(\mathrm{~s}), \quad \Delta G_{3}^{\circ}=-289060+93.52 T^{13,14} \\
& \mathrm{Al}_{2} \mathrm{O}_{3}(\mathrm{~s})+[\mathrm{Ti}]+2[\mathrm{O}]=\mathrm{Al}_{2} \mathrm{O}_{3} \cdot \mathrm{TiO}_{2}(\mathrm{~s}), \\
& \Delta G_{4}^{\circ}=-168940+55.51 T^{12,13,15)} \\
& \mathrm{Ti}_{2} \mathrm{O}_{3}(\mathrm{~s})+2[\mathrm{Al}]=\mathrm{Al}_{2} \mathrm{O}_{3}(\mathrm{~s})+2[\mathrm{Ti}] \text {, } \\
& \Delta G_{5}^{\circ}=-26060+8.27 T^{12-14)} \\
& \mathrm{Ti}_{3} \mathrm{O}_{5}(\mathrm{~s})+10 / 3[\mathrm{Al}]=5 / 3 \mathrm{Al}_{2} \mathrm{O}_{3}(\mathrm{~s})+3[\mathrm{Ti}] \text {, } \\
& \Delta G_{6}^{\circ}=-57767+19.67 T^{12-14)} \\
& \mathrm{Al}_{2} \mathrm{O}_{3} \cdot \mathrm{TiO}_{2}(\mathrm{~s})+4 / 3[\mathrm{Al}]=5 / 3 \mathrm{Al}_{2} \mathrm{O}_{3}(\mathrm{~s})+[\mathrm{Ti}], \\
& \Delta G_{7}^{\circ}=-23767+6.84 T^{12-15)}
\end{aligned}
$$

selecting $\mathrm{Ti}_{2} \mathrm{O}_{3}$ and $\mathrm{Ti}_{3} \mathrm{O}_{5}$ as stable Ti oxides in the investigated range of [Ti], [Al] and $a_{[\mathrm{O}]}$. The standard reaction Gibbs free energy changes $\Delta G^{\circ}$ are expressed in cal $\cdot \mathrm{mol}^{-1}$.

Using the interaction coefficients of Table 4 and the standard reaction Gibbs free energy changes of reactions (1) to (7), the equilibrium diagram of the $\mathrm{Fe}-\mathrm{Al}-\mathrm{Ti}-\mathrm{O}$ system can be drawn at $1620^{\circ} \mathrm{C}$ (Fig. 10). It gives the type of oxides formed at equilibrium as a function of [Al], [Ti] and [O]. Thick lines mark the phase boundaries of the deoxidation products, whereas thin lines delimit the liquid Fe stable region at a given $a_{[\mathrm{O}]}$. The compositions of the steel samples taken after $\mathrm{Ti}$ addition are superimposed on the diagram. The samples containing predominantly $\mathrm{Al}_{2} \mathrm{O}_{3}$ inclusions (solid square markers) are located in the $\mathrm{Al}_{2} \mathrm{O}_{3}$ stable region, while those containing $\mathrm{Ti}-\mathrm{Al}-\mathrm{O}$ complex inclusions (solid dot markers) are close to the calculated line or within the Ti oxide stable region. To prevent [Ti] oxidation during
Table 4. Interaction coefficients used in the present work

\begin{tabular}{cccc}
\hline$i$ & $j$ & $e_{i}^{j}$ & Ref. \\
\hline $\mathrm{O}$ & $\mathrm{Al}$ & -0.83 & $16)$ \\
& $\mathrm{Ti}$ & -0.6 & $17)$ \\
& $\mathrm{O}$ & -0.2 & $17)$ \\
\hline $\mathrm{Al}$ & $\mathrm{Al}$ & 0.045 & $17)$ \\
& $\mathrm{Ti}$ & 0.004 & $18)$ \\
& $\mathrm{O}$ & -1.4 & $16)$ \\
\hline $\mathrm{Ti}$ & $\mathrm{Al}$ & 0.0037 & $18)$ \\
& $\mathrm{Ti}$ & 0.013 & $17)$ \\
& $\mathrm{O}$ & -1.8 & $17)$ \\
\hline
\end{tabular}

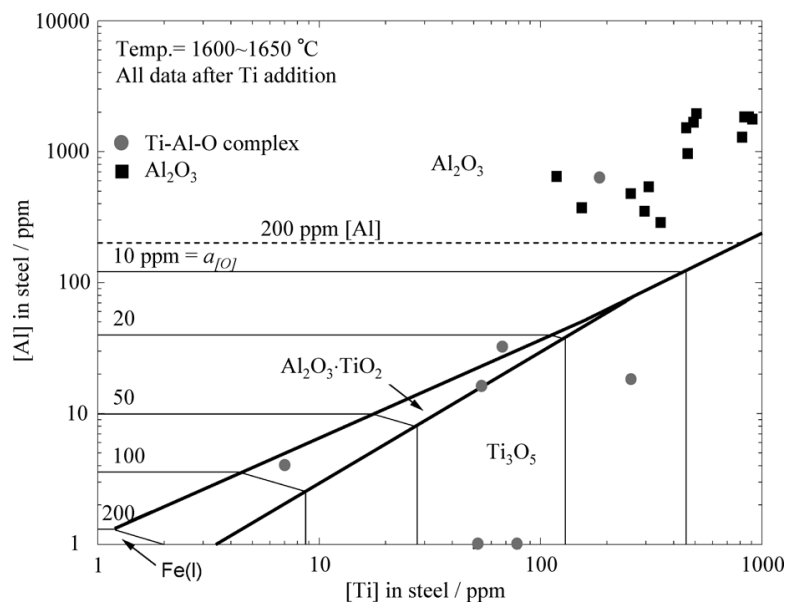

Fig. 10. Equilibrium diagram for the system $\mathrm{Fe}-\mathrm{Al}-\mathrm{Ti}-\mathrm{O}$ at $1620^{\circ} \mathrm{C}$ and various $a_{[\mathrm{O}]}(10$ to $200 \mathrm{ppm})$. Square markers indicate the metal composition of the samples in which $\mathrm{Al}_{2} \mathrm{O}_{3}$ inclusions were found, while round markers correspond to the metal composition of the samples containing Al-Ti-O inclusions.

alloying, it is essential to control [Al] to a sufficiently high value. This required [Al] is determined by the line delimiting the $\mathrm{Al}_{2} \mathrm{O}_{3}$ stable region. According to the calculations and considering that [Ti] is aimed at $525 \mathrm{ppm}$, approximately $200 \mathrm{ppm}$ [Al] is required prior to Ti addition to prevent [Ti] oxidation. This calculated value is consistent with the experimental results depicted in Fig. 10. This is also in a good agreement with the compositional analyses of the inclusions shown in Fig. 6.

\subsubsection{Reaction Mechanism during Al/Ti/Al Deoxidation}

Figure 11 shows, for Exp. 3, the evolution of the liquid steel composition superimposed on the inclusion phase diagram. As indicated by the open circle (point A), the [Ti] and $[\mathrm{Al}]$ at the moment of $\mathrm{Ti}$ addition fell within the $\mathrm{Ti}_{3} \mathrm{O}_{5}$ stable region. This was intentionally controlled by partial Al deoxidation and Ti addition. Just after the addition, [Ti] reacted with oxygen in steel to form Ti oxides, resulting in a decrease of $a_{[\mathrm{O}]}$ and [Ti] (from point A to point $\mathrm{B}$ ). The steel was gradually reoxidized by the residual oxygen in the Ar flow, causing an increase in $a_{[\mathrm{O}]}$ and a decrease of [Ti], while [Al] remained constant (from point $\mathrm{B}$ to point $\mathrm{C}$ ). This is consistent with the fact that the steel composition evolved in the $\mathrm{Ti}_{3} \mathrm{O}_{5}$ stable region, where only Ti oxidation is predicted. The steel composition reached the $\mathrm{Ti}_{3} \mathrm{O}_{5} /$ $\mathrm{Al}_{2} \mathrm{O}_{3} \cdot \mathrm{TiO}_{2}$ phase boundary at point $\mathrm{C}$. By steel reoxidation, both [Ti] and [Al] decrease through reaction with oxygen, as entering the $\mathrm{Al}_{2} \mathrm{O}_{3} \cdot \mathrm{TiO}_{2}$ stable region where both $\mathrm{Al}$ and $\mathrm{Ti}$ oxidation is possible (from point $\mathrm{C}$ to point $\mathrm{D}$ ). 


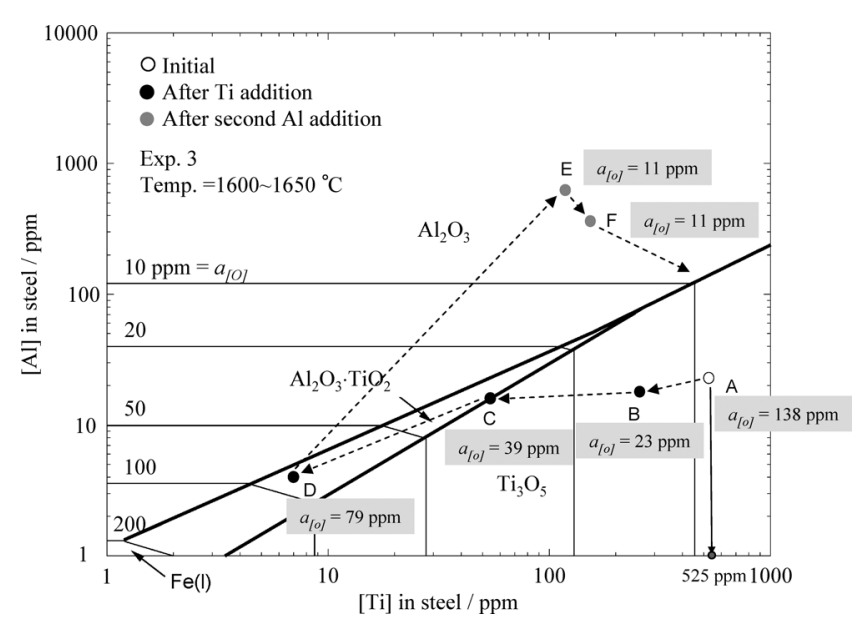

Fig. 11. Evolution of [Ti] and [Al] during Exp. 3, plotted on the computed equilibrium diagram of the $\mathrm{Fe}-\mathrm{Al}-\mathrm{Ti}-\mathrm{O}$ system at $1620^{\circ} \mathrm{C} . a_{[\mathrm{O}]}$ is given next to each point.

Meanwhile, $a_{[\mathrm{O}]}$ increased. [Ti] and [Al] proceeded through the $\mathrm{Al}_{2} \mathrm{TiO}_{5}$ stable region and approached the $\mathrm{Al}_{2} \mathrm{O}_{3} \cdot \mathrm{TiO}_{2} /$ $\mathrm{Al}_{2} \mathrm{O}_{3}$ phase boundary (point $\mathrm{D}$ ), where $\mathrm{Fe}(\mathrm{l})-\mathrm{Al}_{2} \mathrm{O}_{3}$. $\mathrm{TiO}_{2}(\mathrm{~s})-\mathrm{Al}_{2} \mathrm{O}_{3}(\mathrm{~s})$ equilibrium is established. Twenty minutes elapsed between Ti addition (point $\mathrm{A}$ ) and point $\mathrm{D}$. The second $\mathrm{Al}$ addition was then performed. Steel deoxidation and $\mathrm{Ti}$ recovery from $\mathrm{Ti}-\mathrm{Al}-\mathrm{O}$ inclusions simultaneously took place, resulting in a decrease of $a_{[\mathrm{O}]}$ and a considerable increase of [Ti]. Hence, the steel composition moved to the point $\mathrm{E}$, where $\mathrm{Al}_{2} \mathrm{O}_{3}$ is stable. The reduction reaction proceeded with time by consuming [Al] and increasing [Ti] up to point $\mathrm{F}$. This reduction process was also observed during Exp. 2 and 4 (Fig. 8). In the case of strong second Al deoxidation (implying high [Al]), [Ti] and [Al] changed with time, attempting to maximize Ti recovery by consuming [Al] until the $\mathrm{Ti}_{3} \mathrm{O}_{5} / \mathrm{Al}_{2} \mathrm{O}_{3}$ phase boundary is reached.

\section{Conclusions}

(1) Only $\mathrm{Al}_{2} \mathrm{O}_{3}$ inclusions were observed when strong $\mathrm{Al}$ deoxidation prior to Ti alloying was performed. On the other hand, with partially deoxidized steel prior to Ti addition $\left(a_{[\mathrm{O}]}=140-280 \mathrm{ppm}\right)$, Ti deoxidation took place. In that case, large $\mathrm{Al}_{2} \mathrm{O}_{3}$ clusters and small $\mathrm{Ti}-\mathrm{Al}$ oxide particles randomly distributed in the steel were found. After the second $\mathrm{Al}$ addition, only $\mathrm{Al}_{2} \mathrm{O}_{3}$ clusters and few small $\mathrm{Ti}-\mathrm{Al}-\mathrm{O}$ inclusions remained due to the reduction of $\mathrm{Ti}$ oxides by $[\mathrm{Al}]$.

(2) The extent of [Ti] oxidation increased with $a_{[\mathrm{O}]}$ prior to $\mathrm{Ti}$ alloying. No Ti deoxidation occurred with low
$a_{[\mathrm{O}]}$ prior to Ti alloying. On the other hand, increasing the Ti addition to $1500 \mathrm{ppm}$ had no significant effect on Ti deoxidation.

(3) The reduction of $\mathrm{Ti}$ oxides through the second $\mathrm{Al}$ addition was confirmed by inclusion observations and compositional analysis of the samples. Ti recovery from Ti-Al-O inclusions occurred rapidly after the second Al addition and was enhanced by performing the latter shortly after Ti alloying.

(4) The combination of experimental and calculated results shows that, in order to prevent Ti oxidation, it is essential to maintain $[\mathrm{Al}]$ to a sufficiently high value. Approximately $200 \mathrm{ppm}$ [Al] is necessary prior to Ti addition to minimize Ti loss during the alloying process.

(5) The mechanisms of Ti-Al deoxidation reactions involving inclusion formation at various stages of the experiments were elucidated based on the calculated $\mathrm{Fe}-\mathrm{Al}-\mathrm{Ti}-\mathrm{O}$ phase diagram.

\section{REFERENCES}

1) D. C. Park, I. H. Jung, P. C. H. Rhee and H. G. Lee: ISIJ Int., 44 (2004), 1669.

2) M. Ito, K. Morita and N. Sano: ISIJ Int., 37 (1997), 839.

3) K. Yamamoto, S. Matsuda, T. Haze, R. Chijiiwa and H. Mimura: Proc. Int. Symp. Residual and Unspecified Elements in Steel, ASTM International, Philadelphia, PA, (1989), 266.

4) C. Van der Eijk, Ø. Grong, S. S. Babu and S. A. David: Proc. 5th Int. Conf. on Trends in Welding Research, ASM International, Materials Park, OH, (1999), 729.

5) K. Kunisada and K. Iwai: CAMP-ISIJ, 7 (1994), 1130

6) K. Kunisada and K. Iwai: CAMP-ISIJ, 6 (1993), 1173.

7) F. Ruby-Meyer, J. Lehmann and H. Gaye: Scand. J. Metall., 29 (2000), 206.

8) H. Matsuura, C. Wang, G. H. Wen and S. Sridhar: ISIJ Int., 47 (2007), 1265.

9) M. Guo, P. T. Jones, S. Parada, E. Boydens, J. V. Dyck, B. Blanpain and P. Wollants: J. Eur. Ceram. Soc., 26 (2006), 3831.

10) C. Van der Eijk, Ø. Grong and J. Walmsley: Proc. 6th Int. Conf. on Molten Slags, Fluxes and Salts, KTH, Stockholm, (2000).

11) M. Pajunen and J. Kivilahti: Z. Metallkd., 83 (1992), 17.

12) O. Kubaschewski and W. A. Dench: J. Inst. Met., 82 (1953), 87.

13) J. F. Elliott: Proc. Electric Furnace Conf., The Iron and Steel Soc. AIME, Warrendale, PA, (1974), 293.

14) M. W. Chase, J. L. Curnutt, R. A. McDonald and A. N. Syverud: J. Phys. Chem. Ref. Data, 7 (1978), 793.

15) I. Barin, O. Knacke and O. Kubaschewski: Thermochemical Properties of Inorganic Substances (supplement), Springer-Verlag, Berlin, (1977), 1546, 1548.

16) H. Ohta and H. Suito: The Final Report of Ultra Clean Steel Research Group, Thermodynamics of Production of Ultra Clean Steel, ISIJ, Tokyo, (1999), 66.

17) G. K. Sigworth and J. F. Elliott: Met. Sci., 8 (1974), 298.

18) G. Yuanchang and W. Changzhen: Metall. Trans. B, 21B (1990), 543. 